
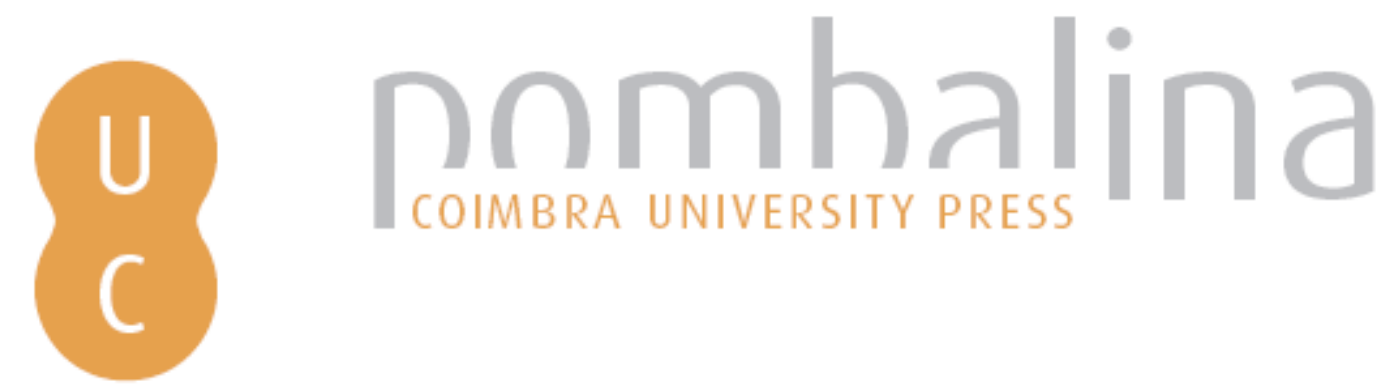

\title{
Amimetobiou, the One "of the Inimitable Life»: Cleopatra as a Metaphor for Alexandria in Plutarch
}

Autor(es): $\quad$ Rodrigues, Nuno Simões

$\begin{array}{ll}\text { Edições Afrontamento; CITCEM - Centro de Investigação } \\ \text { Publicado por: } & \begin{array}{l}\text { Transdisciplinar «Cultura, Espaço e Memória»; Centro de Estudos } \\ \text { Clássicos e Humanísticos; Alexandria University; Imprensa da } \\ \text { Universidade de Coimbra }\end{array}\end{array}$

URL persistente:

URI:http://hdl.handle.net/10316.2/36159

DOI:

DOI:http://dx.doi.org/10.14195/978-989-26-0966-9_4

Accessed : $\quad$ 26-Apr-2023 15:34:58

A navegação consulta e descarregamento dos títulos inseridos nas Bibliotecas Digitais UC Digitalis, UC Pombalina e UC Impactum, pressupõem a aceitação plena e sem reservas dos Termos e Condições de Uso destas Bibliotecas Digitais, disponíveis em https://digitalis.uc.pt/pt-pt/termos.

Conforme exposto nos referidos Termos e Condições de Uso, o descarregamento de títulos de acesso restrito requer uma licença válida de autorização devendo o utilizador aceder ao(s) documento(s) a partir de um endereço de IP da instituição detentora da supramencionada licença.

Ao utilizador é apenas permitido o descarregamento para uso pessoal, pelo que o emprego do(s) título(s) descarregado(s) para outro fim, designadamente comercial, carece de autorização do respetivo autor ou editor da obra.

Na medida em que todas as obras da UC Digitalis se encontram protegidas pelo Código do Direito de Autor e Direitos Conexos e demais legislação aplicável, toda a cópia, parcial ou total, deste documento, nos casos em que é legalmente admitida, deverá conter ou fazer-se acompanhar por este aviso.

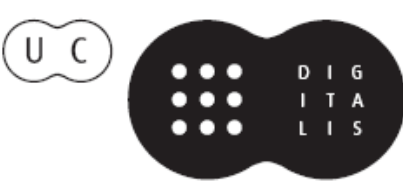




\title{
AMIMETOBIOU, THE ONE «OF THE INIMITABLE LIFE»: CLEOPATRA AS A METAPHOR FOR ALEXANDRIA IN PLUTARCH
}

\section{NUNO SIMÕES RODRIGUES}

University of Lisbon. Centro de História (University of Lisbon). Centro de Estudos Clássicos e Humanísticos (University of Coimbra).

\begin{abstract}
In Life of Antony, Plutarch builds one of the most relevant portraits of Cleopatra VII. However, Plutarch is far from being impartial, as one would expect in a «Historian». Quite the opposite. Plutarch defines the last Lagid Queen as an Alexandrian metaphor. At the same time, she represents the perception that the Greco-Roman mentality in the first centuries of our Era had of the Egyptian city: luxurious, lustful, lazy, exotic, exuberant, deceitful and tricky, as well as sapient.
\end{abstract}

In a Book originally published in the 1970s and more recently re-edited, E. W. Said recuperates the theme of Orientalism in western culture, especially in the 19th and 20th centuries ${ }^{1}$. One of the salient elements stressed by the author is the frequent metaphorisation of the East as a woman whose personality is defined by sensuality and licentiousness as practically innate features.

Following a similar hermeneutical approach, in an article published in 1986, L. Lowe identifies those characteristics as the model used by the famous French novelist G. Flaubert to compose the character of Salammbô in his homonymous novel. Lowe explains how the representation of the East as the cultural opposite of the West in Flaubert's novel is feminised and eroticised so that the Orient becomes a feminine object of devotion ${ }^{2}$. In Flaubert,

\footnotetext{
${ }^{1}$ SAID, 2003: 187-188.

${ }^{2}$ LOWE, 1986: 44-45.
} 
Salammbô the Carthaginian is therefore a metonymy of the eastern world as Rome is a metonymy of the West. The cultural and historical alterity of Carthage as Orient is thus materialised in Salammbô's sexual alterity as a woman ${ }^{3}$.

However, the method identified by Said does not originate in Romanticism ${ }^{4}$. In a parallel exegesis, the character of Dido in the Aeneid is commonly said to evoke that of Cleopatra VII Philopator ${ }^{5}$. In fact, although the character does suggest a metonymy of Carthage ${ }^{6}$, the way Vergil defines her - as an obstacle to the success of Aeneas' mission, a symbol of the Orient, a fatal woman - seems to be based especially on the composition of the last Lagid queen of Egypt, who was protagonist to the most relevant political event of her time and who for that same reason came to be remembered in the Aeneid. A more detailed analysis suggests that, in her coeval political context, Cleopatra is more than just a symbol of Egypt, of the whole East, and of what it represents for Rome. As a matter of fact, when, in the preActium context, Octavian declares war on the queen, not only does he turn the attention of the Roman public opinion from Mark Antony, who was in fact his real target and whom he wanted to use for the benefit of his own political agenda, but he uses Cleopatra again as a metonymy of what the East signified for the western Roman power. It was therefore a skilled political maneuver sustained by the efficient Roman propaganda machine.

This coincides with what we can read in Plutarch. In fact, as I see it, in Life of Antony Plutarch uses the same artifice, or the same technique, to compose the personality of Cleopatra VII. In Plutarch's text, the queen of Egypt becomes mostly a metonymy, this time a metonymy of the city of Alexandria, since the Greek author describes her through the same essential characteristics that define the Orient in the Roman imaginary, of which the Greco-Egyptian city then becomes the paradigm. This «rule» is confirmed in the way the writer from Chaeronea composes the personality of the female descendant of the Lagids. From his viewpoint, both sensuality and licentiousness become key features in the queen's definition. The following passage can be read as an illustration of exactly that:

Such, then, was the nature of Antony, where now as a crowning evil his love for Cleopatra supervened, roused and drove to frenzy many of the passions that were still hidden and quiescent in him, and dissipated and destroyed whatever good and saving qualities still offered resistance. And he was taken captive in this manner. As he was getting ready for the Parthian war, he sent to Cleopatra, ordering her to meet him in Cilicia in order to make answer to the charges made against her of raising and giving to Cassius much money for the war. But Dellius, Antony's messenger, when he saw how Cleopatra looked, and noticed her

\footnotetext{
${ }^{3}$ LOWE, 1986: 46.

${ }^{4}$ See also ADLER, LÉCOSSE, 2010; MENON, 2006; BILLINGHURST, 2004; DIJKSTRA, 1988.

${ }^{5}$ See e.g. ROCHA PEREIRA, 2002: 260; PELLING, 1994: 17-18, 220; GRIFFIN, 1999: 194; OGLE, 1925: 261-270.

${ }^{6}$ See e.g. ROCHA PEREIRA, 2002: 270.

${ }^{7}$ Verg. Aen. 8.650-704.
} 
subtlety and cleverness in conversation, at once perceived that Antony would not so much as think of doing such a woman any harm, but that she would have the greatest influence with him. He therefore resorted to flattery and tried to induce the Egyptian to go to Cilicia «decked out in fine array" (as Homer would say), and not to be afraid of Antony, who was the most agreeable and humane of commanders. She was persuaded by Dellius, and judging by the proofs which she had had before this of the effect of her beauty upon Caius Caesar and Gnaeus the son of Pompey, she had hopes that she would more easily bring Antony to her feet. For Caesar and Pompey had known her when she was still a girl and inexperienced in affairs, but she was going to visit Antony at the very time when women have the most brilliant beauty and are at the acme of intellectual power.

In Plutarch, the perspective of analysis and of synthesis is also defined through an androcentric, or maybe even a Greco-Roman-centric, axis for which being a woman and being Eastern is a dichotomy which «invents the East as the feminine counterpart to a masculine West $»{ }^{9}$. As happens in the 19th century, this rhetoric of difference is achieved through the topos of sexual or gender differentiation, sexuality becoming a privileged field of reference.

These are expressed in Life of Antony, in passages such as «where now as a crowning evil his love for Cleopatra supervened, roused and drove to frenzy many of the passions that were still hidden and quiescent in him, and dissipated and destroyed whatever good and saving qualities still offered resistance» ${ }^{10}$.

Plutarch is careful to mention that Antony first met Cleopatra when she was a mature woman, in the prime of her womanhood, when her splendour, her charm and her powers of persuasion were at their strongest. With this, the author clearly signals the tribune's weakness before the sensuality of the Oriental queen ${ }^{11}$. Indeed, the episode where the arrival of the queen's barge to Cydnus is described is particularly significant as an expression of that erotic sensuality. Note how Plutarch resorts to a Hellenic-inspired typology (we should remember that Cleopatra was of Greek origin), though he emphasizes those elements of the scenery that are more directly relevant to the orientalising quality of the context:

She herself reclined beneath a canopy spangled with gold, adorned like Venus in a painting, while boys like Loves in paintings stood on either side and fanned her. Likewise also the fairest of her serving-maidens, attired like Nereïds and Graces, were stationed, some at the rudder-sweeps, and others at the reefing-ropes. Wondrous odours from countless incense-

\footnotetext{
${ }^{8}$ Plu. Ant. 25.

${ }^{9}$ LOWE, 1986: 45.

${ }^{10}$ Plu. Ant. 25.

${ }^{11}$ Plu. Ant. 25. However, Plutarch notes that men's fascination for her resided not in her beauty but rather in other characteristics such as her voice; see Plu. Ant. 27.
} 
offerings diffused themselves along the river-banks. Of the inhabitants, some accompanied her on either bank of the river from its very mouth, while others went down from the city to behold the sight. The throng in the market-place gradually streamed away, until at last Antony himself, seated on his tribunal, was left alone. And a rumour spread on every hand that Venus was come to revel with Bacchus for the good of Asia ${ }^{12}$.

The visual nature of the description, deliberately highlighted through comparisons with painting, and the predominance of musical images which convey an orientalising atmosphere do, in fact, promote the Levantine character of the protagonist, who embodies all the categories implied in the concept, notably that of lust $\mathrm{t}^{13}$.

The Cydnus barge episode is also a metaphor for a certain opulence which, like lust, is associated with the construction of the western image of the East, including lust and luxury in the same category. The scene is indeed prepared on the basis of the shadow of wealth and luxury as reference points. For example, Plutarch describes how Cleopatra prepared riches and adornments to welcome Antony ${ }^{14}$. The author also mentions the luxury patent in most of Antony and Cleopatra's fleet ${ }^{15}$. The luxury of this regal atmosphere is also highlighted in the description of the tomb's contents and generally in the death scenario prepared by Cleopatra as an allegory of, and a corollary to, the queen's life in her lover's company:

and she [Cleopatra] herself, now that she had a tomb and monument built surpassingly lofty and beautiful, which she had erected near the temple of Isis, collected there the most valuable of the royal treasures, gold, silver, emeralds, pearls, ebony, ivory, and cinnamon; and besides all this she put there great quantities of torch-wood and tow, so that Caesar was anxious about the reason, and fearing lest the woman might become desperate and burn up and destroy this wealth, kept sending on to her vague hopes of kindly treatment from him, at the same time that he advanced with his army against the city ${ }^{16}$.

Indeed, Cleopatra's riches reflect those of the Orient ${ }^{17}$. Those are the elements that afford an inimitable atmosphere and a way of life that is foreign to the Roman, or even the Greek, character, as may be understood through M. H. da Rocha Pereira's synthesis of Roman mentality ${ }^{18}$. The so called synodos ton Amimetobion has its origin in that somewhat

\footnotetext{
12 Plu. Ant. 26.

${ }^{13}$ Cf. PARKER, 2002: 40-95.

${ }^{14}$ Plu. Ant. 25-26.

${ }^{15} \mathrm{Plu}$. Ant. 61. It should also be noted that the tradition, or myth, according to which Cleopatra used to drink pearls dissolved in vinegar seems to convey exactly the same idea of luxury and excess. Cf. B. L. ULLMAN, 1957: 193-201.

${ }^{16}$ Plu. Ant. 74; cf. 25; 85.

${ }^{17}$ Plu. Ant. 78. On this, see e.g. the descriptions of Babylon in Hdt. 1.

${ }^{18}$ ROCHA PEREIRA, 2002: 332-429.
} 
unbridled context ${ }^{19}$. Actually, though, excess is not the only central motif in these descriptions. To it there can be added futility, defined through a life of leisure, puerility and carelessness, precisely the type of life that led Antony and Cleopatra's contemporaries, and Plutarch, to describe the couple as «the Inimitable Livers $»^{20}$. As Plutarch writes,

[t] here, indulging in the sports and diversions of a young man of leisure, he squandered and spent upon pleasures that which Antiphon calls the most costly outlay, namely, time. For they had an association called The Inimitable Livers, and every day they feasted one another, making their expenditures of incredible profusion $n^{21}$.

Following this conceptualisation, however, the Greek author makes a point of stressing the general's very Roman rustic character in contrast with the queen of Egypt's oriental sophistication, thus emphasising this quality of Cleopatra's ${ }^{22}$.

The Alexandrian banquets, as described by Plutarch in the tribune's biography, also emerge as metaphors for luxury and moral decline with the guests being interested only in eating, drinking, and presents. Alexandria is presented as an idle town, given over to impious merrymaking and festivities sine dignitate ${ }^{23}$. The following passage affords a clear example of that:

Antony sent, therefore, and invited her to supper; but she thought it meet that he should rather come to her. At once, then, wishing to display his complacency and friendly feelings, Antony obeyed and went. He found there a preparation that beggared description, but was most amazed at the multitude of lights. For, as we are told, so many of these were let down and displayed on all sides at once, and they were arranged and ordered with so many inclinations and adjustments to each other in the form of rectangles and circles, that few sights were so beautiful or so worthy to be seen as this ${ }^{24}$.

Clearly, the sumptuousness of the banquet as it is described has the same symbology. In fact, the text finds an echo in a similar passage in Petronius' Satyricon ${ }^{25}$, the purpose

\footnotetext{
${ }^{19}$ Plu. Ant. 28; 71.

${ }^{20}$ Perhaps this club, as noted by PELLING, 1994: 195, had the religious meaning of the dionysiac thiasos type. In fact, the word synodos suggests a religious connotation.

${ }^{21}$ Plu. Ant. 28.

${ }^{22} \mathrm{Plu}$. Ant. 27: «On the following day Antony feasted her in his turn, and was ambitious to surpass her splendour and elegance, but in both regards he was left behind, and vanquished in these very points, and was first to rail at the meagerness and rusticity of his own arrangements. Cleopatra observed in the jests of Antony much of the soldier and the common man, and adopted this manner also towards him, without restraint now, and boldly». On the rustic character of the Roman, see the legend of Cincinnatus in Liv. 3.26.7-11 and ROCHA PEREIRA, 2002: 399.

${ }^{23}$ Plu. Ant. 26; 71. On the concepts of cum and sine dignitate, see ROCHA PEREIRA, 2002: 388-397.

${ }^{24}$ Plu. Ant. 26; cf. 27-28.

${ }^{25}$ Petr. Sat. $28-40$.
} 
being to accentuate the eastern ambience and give it a pejorative barbarian character. Note how the East is depreciated in Petronius' text ${ }^{26}$. In a different passage, the contrast is drawn through a description of the splendid banquet representing the idea of decadence, in a Bacchic antagonism with, at that moment, silent Alexandria:

During this night, it is said, about the middle of it, while the city was quiet and depressed through fear and expectation of what was coming, suddenly certain harmonious sounds from all sorts of instruments were heard, and the shouting of a throng, accompanied by cries of Bacchic revelry and satyric leapings, as if a troop of revellers, making a great tumult, were going forth from the city; and their course seemed to lie about through the middle of the city toward the outer gate which faced the enemy, at which point the tumult became loudest and then dashed out ${ }^{27}$.

Again, the description emphasises the theme of excess. Similarly, the Synapothanoumenon, or Society of Partners in Death, can be seen as continuous with the principle presented before - Epicurean on the one hand, Stoic on the other: indulging in pleasures that lead to death, to moral decline, to the total loss of dignity, albeit with no less luxury ${ }^{28}$.

Plutarch also mentions the games and childish follies ${ }^{29}$, in which the courtesans, including the queen and the tribune, indulged, and he goes so far as identifying what, from a Roman viewpoint, would be masculine, not feminine, functions as attributes of the Egyptian queen, thereby stressing eastern alterity by association with the female universe $\mathrm{e}^{30}$. The most significant of these functions is the active exercise of politics, which corresponds by definition to the very statute of a queen ${ }^{31}$ and consolidates the identification with the Herakles and Omphale myth, which we shall mention again later.

This, then, is a synthesis of the Oriental mode of existence, inevitably associated with Alexandria, a city that was seen as the capital of political degeneration at the time, a threat to Roman hegemony, having therefore an extremely negative image. One of the most significant descriptions of that perception of the city can be read in Life of Antony 29:

But Cleopatra, distributing her flattery, not into the four forms of which Plato speaks, but into many, and ever contributing some fresh delight and charm to Antony's hours of seriousness or mirth, kept him in constant tutelage, and released him neither night nor day. She played at dice with him, drank with him, hunted with him, and watched him as he exercised

\footnotetext{
${ }^{26}$ See e.g. RODRIGUES, 2004: 77-95.

${ }^{27}$ Plu. Ant. 75.

${ }^{28}$ Plu. Ant. 71; PELLING, 1994: 295.

${ }^{29}$ Plu. Ant. 26; 28-29; 71.

${ }^{30}$ Plu. Ant. 29-30.

${ }^{31}$ Plu. Ant. 76.
} 
himself in arms; and when by night he would station himself at the doors or windows of the common folk and scoff at those within, she would go with him on his round of mad follies, wearing the garb of a serving maiden. For Antony also would try to array himself like a servant. Therefore he always reaped a harvest of abuse, and often of blows, before coming back home; though most people suspected who he was. However, the Alexandrians took delight in their graceful and cultivated way; they liked him, and said that he used the tragic mask with the Romans, but the comic mask with them ${ }^{32}$.

What we have here is a portrait of a courtesan life identified with the orientalising modus uiuendi, utterly inadequate to the personality of the mores romani ${ }^{33}$.

Those heedless frivolities lead Antony to be dominated by passion ${ }^{34}$, losing his selfcontrol, his moderation - which is one of the cardinal Platonic virtues (sophrosyne) ${ }^{35}-$, and behaving in an immoderate manner.

What we see in Plutarch's description is, in fact, a negative conversion, that is, the degeneration of a good soldier into an individual contaminated with eastern vices, in consonance with the world he now moves in, with Cleopatra as its major figure. As a lover wounded by Eros' weapons, Antony becomes weak and debilitated, struck by the most terrible plague, torpid and neutralised by the force of those influences ${ }^{36}$. In an extraordinary rhetoric sleight of hand, even the name of the slave in the suicide episode is chosen for its symbolic resonances: Eros, homonymous with the divine and tragic forces that contribute to the destruction of the Roman general ${ }^{37}$.

The tribune's intoxication - for Antony drowns in wine his inability to manage the passion he feels for the queen ${ }^{38}$ - is also symbolic of eastern leisure/immoderation, manifest in such luxuries and behaviours as the Romans consider unbridled. Plutarch's text mentions the tekhnitai Dionyson ${ }^{39}$, possibly a group or a community associated with Dionysos the god and who spent most of their lives partying or going to the theatre. The fact that his blind passion for Cleopatra interferes with Antony's political duties is also a sign of that intromission, showing utter disrespect for public life ${ }^{40}$.

\footnotetext{
32 Plu. Ant. 29.

${ }^{33}$ Note that Suet. Nero 21, e.g., uses the same artifice to stain the image of the emperor, and Caligula's biography by the same author generally follows that same tendency.

${ }^{34}$ Plu. Ant. 36.

${ }^{35}$ Plat. Rep. 427e.

${ }^{36}$ Plu. Ant. 36-37.

${ }^{37}$ Plu. Ant. 76. For some Roman currents other than the Stoic and expressed e.g. in Verg. Aen. 6, suicide was condemnable, which seems to have contributed to the decline of Antony's image. Other interpretations may view the general's decision to take his own life as a last act of dignity.

${ }^{38}$ Plu. Ant. 51; 59.

${ }^{39}$ Plu. Ant. 57.

${ }^{40}$ Plu. Ant. 58.
} 
Another element associated with luxury is effeminate sexuality (which should not be understood as what we now call homosexuality, since practices of a homosexual nature are not necessarily of an effeminate type; in Antiquity, while the former were not even an issue, the latter were disliked by society, since they were associated with sexually passive behaviour). This factor was particularly related to the Dionysian environment, also an object of criticism pejoratively judged by Greco-Roman society ${ }^{41}$. In Plutarch, Antony is presented as playing effeminate roles, precisely in a context of Dionysian cultural practices ${ }^{42}$.

This composition clearly suggests the myth of Herakles and the queen of Lydia, in which there is an inversion of social and anthropological roles, with Herakles, the male hero, having a feminine role, and Omphale, the female character, performing the masculine part $^{43}$. The issue here was obviously the construction of an image whereby the queen of Egypt, a woman, was in most aspects set above Antony, the man.

The theme was sufficiently well-known in Antiquity and Antony significantly identifies himself as a descendant of Herakles ${ }^{44}$. On the other hand, the hero of the Twelve Labours was commonly associated with Dionysian performances ${ }^{45}$. Plutarch's text goes as far as suggesting that Antony might have cross-dressed, transvestitism being a practice with Bacchian resonances ${ }^{46}$.

However, by identifying Marc Antony as the husband of two wives, Octavia and Cleopatra, as Plutarch does in his biography of the Roman tribune, the author again presents the character in connection with degenerated Orientalism, which represents the opposite of what the Romans believed $\mathrm{in}^{47}$. It should however be noted that polygamy was particularly important for the Pharaohs, the Egyptian royalty in the apogee of Nilotic civilization, and decisively marked its physiognomy. In contrast, Augustus' family laws, which partly included a regulation of sexual practices, were extremely severe ${ }^{48}$.

Another trait the Romans seemed to associate to Cleopatra as a suggestion of her Oriental otherness is her character as a magician or a sorcerer. It is important to note that in Greco-Roman literature witches and sorcerers are often depicted as characters from beyond frontiers, that is, as «others» ${ }^{49}$. To cite some examples, there is Medea, from Tessalia - recreated in Argonautica by Apollonius of Rhodes, an Alexandrian intellectual; Circe, of Ea, an

\footnotetext{
${ }^{41}$ On this see WILLIAMS, 2010; WILLIAMS, 1995: 517-539; VEYNE, 1982: 26-33; see also Euripides, Bacchae, a play that represents Dionysos as an effeminate entity.

${ }^{42}$ Plu. Ant. 53, 58.

${ }^{43}$ Apollod. Bibliotheca 2.6.3; Ov. Her. 9.55; D.S. 4.31.

${ }^{44}$ According to Plutarch, the Antonii claimed to be descendants of Herakles through Anton. See Plu. Ant. 4; 36; 60; 76; see also RODRIGUES, 1999: 217-259.

${ }^{45}$ E.g. KUZNETSOVA, 1998.

${ }^{46}$ Plu. Ant. 29.

${ }^{47}$ Plu. Ant. 91; cf. SCOTT, 1933: 7-49.

${ }^{48}$ See e.g. TEIXEIRA, 2007: 361-366.

${ }^{49}$ The theme is also present in Josephus; see RODRIGUES, 1999: 217-259.
} 
island lost in the middle of the Homeric ocean, which in itself constitutes an extended metaphor for alterity and strangeness; Lucan's effera Erictho, another especially terrifying Tessalian witch; and also Apuleius' sorcerers ${ }^{50}$.

Plutarch seems to follow that line of characterization, apparent, for instance, in his referring Cleopatra simply as Aigyptia $a^{51}$. The author repeatedly suggests that the queen kept the Roman tribune under her spell and poisoned him with herbs, causing him to lose his self-control ${ }^{52}$. In a different passage, her experiments, undertaken with the intent to procure the most effective deadly poison are presented as a witch's maneuvers in the search of a powerful potion ${ }^{53}$. Created by Theocritus the Alexandrian, Simaetha is another witch whose behavior has parallels with that of Cleopatra ${ }^{54}$. A taste for the esoteric is associated with the East and, in this particular case, with Alexandria. Also the queen's dissimulations are coherent with the image of a sorcerer, since her charm weapons include cunning, pretence and manipulation ${ }^{55}$. Cleopatra decides to pretend that she is lovesick for the Roman tribune, going so far as to lose weight through a diet in order to deceive her lover into the belief that she was consumed by passion:

She therefore pretended to be passionately in love with Antony herself, and reduced her body by slender diet; she put on a look of rapture when Antony drew near, and one of faintness and melancholy when he went away. She would contrive to be often seen in tears, and then would quickly wipe the tears away and try to hide them, as if she would not have Antony notice them. And she practised these arts while Antony was intending to go up from Syria to join the $M e d e^{56}$.

Thus, there is also seduction of an erotic type (similar to the seduction Jason and Ulysses are objects of in their relationship with their respective female partners) to which men can hardly resist. In fact, what really defines Antony as an anti-hero in this context is precisely the fact that he is not strong enough to be able to resist the charms of Cleopatra the magician. Here the disguises, dissimulations and masks generally present in the Plutarchean text seem to somehow come together ${ }^{57}$.

\footnotetext{
${ }^{50}$ A. R. Arg.; Od. 10; Luc. Fars. 6.508, 640, 725, 826; Apul. Met. passim.

${ }^{51} \mathrm{Plu}$. Ant. 25. In spite of being the queen of Egypt, Cleopatra was not an Egyptian. The image of Egyptians was from Antiquity commonly identified with a mastery of the esoteric; therefore besides ascribing barbarism to the queen other connotations were also mobilized. In Verg. Aen. 8.688, the same reference is used when she is referred as Aegyptia coniunx.

${ }^{52}$ E.g. Plu. Ant. 60; 72.

${ }^{53}$ Plu. Ant. 71.

${ }^{54}$ Theocr. Id. 2; Plu. Ant. 60. On this see SILVA, 2008. One wonders whether Cleopatra's character in Plutarch is not indebted to Theocritus' Simaetha.

${ }^{55}$ Plu. Ant. 53; 76.

${ }^{56}$ Plu. Ant. 53.

${ }^{57}$ Plu. Ant. 29; 53.
} 
Poisons, a domain in which Cleopatra seems to move with ease, can also be seen as an Oriental topos. In Latin historiography, for example, Germanicus, the son of Antonia and Tiberius' rival, is poisoned after making a trip to the East ${ }^{58}$. The case of Circe can again be mentioned: in her Odyssey episode, «potions» and «filters» are centrally important ${ }^{59}$.

Such command and control of the esoteric also gives the character an image of crudelitas, also not without Eastern connotations, while it depicts Cleopatra as an autonomous and enterprising woman. The queen's cruel disposition can perhaps be compared with that of other oriental female monarchs celebrated in Herodotus ${ }^{60}$. Here one can find characters of queens which often have active, autonomous roles. And what greater autonomy could there be than the exercise of power in the domain of the political. That in itself would be enough to explain the treason evoked and perpetrated by the queen of Egypt ${ }^{61}$, including her forever in the company of the odious in the Greco-Roman imaginary (and again quoting the Aeneid, we are reminded of the traitors' place in the economy of Vergil's poem ${ }^{62}$. It is that same autonomy that enables Cleopatra, a cunning woman, to exert her alluring power and fulfill her otherwise unattainable aims ${ }^{63}$.

One last aspect should now be mentioned concerning this metonymic characterization of Cleopatra in her relationship to the Orient as a whole and, more specifically, with Alexandria. If the previously listed elements (luxury, idleness, magic or deceit) can be considered to be negative qualities, now the character's definition includes a positive element, i.e., her erudition. The queen is presented as a woman who valorizes knowledge and literature, which, as is easily understood, also reflects the image of Alexandria. Cleopatra as an erudite woman is clearly perceptible in the passage where Plutarch mentions the fact that the queen could speak seven different languages:

For her beauty, as we are told, was in itself not altogether incomparable, nor such as to strike those who saw her; but converse with her had an irresistible charm, and her presence, combined with the persuasiveness of her discourse and the character which was somehow diffused about her behaviour towards others, had something stimulating about it. There was sweetness also in the tones of her voice; and her tongue, like an instrument of many strings, she could readily turn to whatever language she pleased, so that in her interviews with Barbarians she very seldom had need of an interpreter, but made her replies to most of them herself and unassisted, whether they were Ethiopians, Troglodytes, Hebrews, Arabians, Syrians, Medes or Parthians. Nay, it is said that she knew the speech of many other peoples also,

\footnotetext{
58 Tac. Ann. 2.47-88.

${ }^{59} \mathrm{Od}$. 10. The character of Martha the Syrian prophetess, in Plu. Mari. 17, may be said to share some of these features.

${ }^{60} \mathrm{Plu}$. Ant. 77. In Hdt. 7-9, about queen Artemisia of Halicarnassus and queen Amestris, the reader becomes acquainted with the former's power and the latter's cruelty.

${ }^{61}$ Plu. Ant. 73; 76.

${ }^{62}$ Verg. Aen. 6.608-622.

${ }^{63}$ Plu. Ant. 53.
} 
although the kings of Egypt before her had not even made an effort to learn the native language, and some actually gave up their Macedonian dialect ${ }^{64}$.

This character description, however, is far from being innocent since the author makes a point of mentioning Cleopatra's mellifluous speech, strongly suggesting a deceitful, manipulative woman.

Lust and licentiousness, luxury and idleness, magic and superstition, cruelty and deceitfulness - and also envy ${ }^{65}$ : these are the main features of Cleopatra's portrait in Plutarch. To them we can add erudition/knowledge, which are the exception to the negative tenor of the character's construction and possibly the only positive traits identifiable in the last queen of Egypt ${ }^{66}$. Simultaneously, those are the same items that concur to form an image of Alexandria, itself a metonymy of the Orient, in the Roman mind frame that constructs and reflects it. It is certainly in the Other that alterity is better defined and gains stronger consistency ${ }^{67}$. By adding the character of Mark Antony, the figure that in Plutarch's text almost blends for a moment with the figure of his partner Cleopatra, as if nonexistent except in connection with her, the concept of the Orient as deviant is emphasized. If in those parts women are magicians, witches, impostors, if they are lustful, idle, luxurious, cruel, cunning, too erudite, often in control of events, then men are effeminate, weak, subordinate, permissive and less wise. The same description applies to the kings or even the despots of the East: everything a Roman man should not be; everything a Roman woman is not supposed to be ${ }^{68}$. In contrast to it, one can read the passage where Antony, dressed in his armour, humiliates himself, submissively presenting one of the bravest soldiers of his army to the queen, as though she were the one to whom he had a duty to report: «Then, exalted by his victory, he went into the palace, kissed Cleopatra, all armed as he was, and presented to her the one of his soldiers who had fought most spiritedly» ${ }^{69}$. A final comparison seems to be especially pertinent here: Cleopatra and Helen, both seen as femmes fatales in western tradition, both connected with eastern cities - Alexandria and Troy. Both

\footnotetext{
${ }^{64}$ Plu. Ant. 27.

${ }^{65}$ Plu. Ant. 57.

${ }^{66}$ It is of course positive from our point of view, not necessarily from Plutarch's or any other Ancient author's. In fact, rhetorically, even this feature can be presented as negative feature in the queen's character, especially when compared with Antony's. ${ }^{67}$ Cf. HARTOG, 1991.

${ }^{68}$ As an example of what was expected from the Roman matron, see the famous Epitaph for Claudia (Rome, 2nd century B.C.; ILLRP 973=ILS 8403=CLE 52=CIL I2.1211=CIL VI.15346; SHELTON, 1988, 45.1 ES: "Stranger, I have only a few words to say. Stop and read them. - This is the unlovely tomb of a lovely woman. Her parents named her Claudia. She loved her husband with all of her heart. She bore two sons; one of these she leaves on earth, the other she has already placed under the earth. She was charming in speech, yet pleasant and proper in manner. She managed the household well. She spun wool. I have spoken. Go on your way».

${ }^{69}$ Plu. Ant. 74.
} 
Cleopatra and Helen emerge as female figures that lead men to perdition, e.g., Antony, Achilles, Paris, and Hector. As queens, both are portrayed as the cause of wars that lead to the destruction of those who engage in them ${ }^{70}$. Consequently, it might not be inadequate to give the last queen of Egypt the epithet of «Cleopatra of Alexandria».

In conclusion, Plutarch's Cleopatra represents aspects of an undesired Orientalism and can in fact be read as a portrait of a whole city, Alexandria, itself the image of a whole culture and a whole civilization.

\footnotetext{
${ }^{70}$ Plu. Ant. 56; 62.
} 